\title{
Review of Rasashastra Dravya in Classical text of Ayurveda - Kashyap Samhita
}

\author{
Review Article
}

\section{Vaibhav B Yeokar ${ }^{1 *}$, Raman S Belge ${ }^{2}$, Tuleshwar M Dhaskat ${ }^{3}$, Vinod M Ramteke ${ }^{3}$, Komal P Motghare ${ }^{1}$, Shrikant A Solanke ${ }^{1}$}

\author{
1. PG scholar, 2. Professor and HOD, 3. Associate Professor (Retd.), 4. Dravyaguna, 2. Professor, \\ Department of Rasashastra and Bhaishajya Kalpana \\ Shri Ayurved Mahavidyalaya, Nagpur
}

\begin{abstract}
Ayurveda is science of life. Ayurveda not only focuses on curing of diseased individual but also gives importance to maintenance of health of healthy person.

Ayurveda is basically divided in Ashtangas (Eight Appendages). All these Ashtangas represents specific field of expertise in Ayurveda context. Out of these eight, Kaumarbhritya is field related to care of children. Kashyap Samhita is considered as the masterpiece of texts related to Kaumarbhritya. Kashyap Samhita was written by Acharya Kashyap, in the same time during which Charak Samhita was written.

Rasashastra is study of use of metallic and mineral compounds for preparation of mineral \& herbomineral formulations. References of Rasashastra being a specialty are found in classical texts since 800 A.D. But, there are some references scattered in various Samhitas regarding use of Rasashastra Dravyas. Kashyap Samhita being one of the old Samhitas is also not an exception to this.

In this review article, an attempt was made regarding unveiling the references of Rasashastra Dravya in Kashyap Samhita and it was noted that a lot of references of Rasashastra Dravya are there in Kashyap Samhita in form of either internal administration or external application or for giving Drushtant (example).
\end{abstract}

Keywords: Rasashastra, Kashyap Samhita, Rasadravya, Kaumarbhritya.

\section{Introduction}

Ayurveda is not only science of health focused on curing of diseased individual; rather, it is a science of life. The primary aim of Ayurveda is maintenance of health of healthy person while curing diseased person is a secondary objective.(1)

To achieve these objectives, Ayurveda treaties have led a few principles on which Ayurveda system works. These principles are known as "Sidhhanta". While studying Ayurveda, it is essential to keep in mind these Sidhhanta.

Ashtanga Ayurveda is a term granted for collection of eight specialties of Ayurveda.(2) They may be termed as eight appendages of Ayurveda health system. One of the important appendage is

*Corresponding Author:

\section{Vaibhav B Yeokar}

PG Scholar

Dept. of Rasashastra and Bhaishajya Kalpana

Shri Ayurved Mahavidyalaya, Nagpur, India.

Email: dr.vaibhav.yeokar@gmail.com

Ph.No: +91-9970678324
Kaumarbhritya. In Kaumarbhritya facts related to child care right from childbirth is studied. Kaumarbhritya is branch of Ayurveda where study of nutrition of child, Dhaatri Ksheer Dosh Chikitsa, Baalgraha and treatment of child is studied.(3) Acharya Kashyap or Vrudhhajivaka are known as pioneer in Kaumarbhritya with their manuscript named Kashyap Samhita or Vrudhhajivaka Tantra. Kashyap Samhita focuses their importance on child care, but also there are some references which make it complete from Ashtanga Ayurved point of view.

Kashyap Samhita is also known as Vilupta Tantra because larger part of this Samhita is missing. It was revised by Nepal Rajguru Pandit Hemaraj Sharma, with the help of old incomplete manuscript available in their library. In present scenario, only 77 Adhyaaya (Chapters) are available partially out of 200 Adhyaaya of Kashyap Samhita. This Samhita would have been as good and important as Charak and Sushrut Samhita but as larger part of this Samhita is missing today, led to the fact that lesser importance is being given to it. Presence of Khilsthan is said to be the specialty of Kashyap Samhita. 
Table No. 1: Showing distribution of Adhyaayas of Kashyap Samhita

\begin{tabular}{|c|c|c|c|}
\hline $\begin{array}{c}\text { Sr. } \\
\text { No. }\end{array}$ & Sthaan & $\begin{array}{c}\text { No. of } \\
\text { Adhyaaya } \\
\text { in original } \\
\text { Samhita }\end{array}$ & $\begin{array}{c}\text { No. of } \\
\text { Adhyaaya in } \\
\text { present } \\
\text { Samhita }\end{array}$ \\
\hline 1 & Sutrasthan & 30 & $\begin{array}{c}1,19 \text { to } 28 \\
11\end{array}$ \\
\hline 2 & Nidansthan & 08 & 00 \\
\hline 3 & Vimansthan & 08 & 02 \\
\hline 4 & Sharirsthan & 08 & 05 \\
\hline 5 & Indiyasthan & 12 & 01 \\
\hline 6 & $\begin{array}{c}\text { Chikitasastha } \\
n\end{array}$ & 30 & 18 \\
\hline 7 & Sidhhisthan & 12 & 08 \\
\hline 8 & Kalpasthan & 12 & 09 \\
\hline 9 & Khilsthan & 80 & 23 \\
\hline & Total & $\mathbf{2 0 0}$ & $\begin{array}{c}\mathbf{7 7} \\
\text { ( Some are } \\
\text { incomplete) }\end{array}$ \\
\hline
\end{tabular}

Rasashastra is a science where study of metals, minerals, poisonous compounds useful in preparation of medicine is studied. Rasashastra preparations i.e. Rasaushadhi are known to be useful in minute quantity, quick acting and do not produce aversion reaction in patients due to their tastelessness.(4) The references of Dravya mentioned in Rasashastra, are found since Charak \& Sushrut Samhita.(5)(6). But it was only after $8^{\text {th }}$ century A.D. that practical use of Rasaushadhi started to flourish.

Acharya Nagarjuna are considered as the pioneer of Rasashastra. It is because of Rasashastra that study of alchemy was given so much importance those days. The main aim of Rasashastra is to achieve Moksha. The reason behind Moksha achieved with help of Rasaushadhi is considered to be the healthy life procured by person after consuming them.(7)

Kashyap Samhita being as old as Charak Samhita has number of places where use of Rasadravya either in form of internal administration or external application or for manufacturing a device or to give as a Drushtant (example) is made. Here, those references have been collected, categorized and tabulated in order to understand the use of Rasadravya in period of Kashyap Samhita.

\section{Objectives}

- To collect references of Rasadravya explained in Kashyap Samhita

- To categorize these references according to their types (Internal/ External use, Manufacturing of equipment etc.)

- To establish the state of use of Rasadravya in Samhita Kaal.

Material and Methods

This paper serves as a collection of references pertaining to minerals, metals and poisonous drugs during period of Kashyap Samhita, along with some information on these minerals, metals and poisonous drugs explained in textbooks of Rasashastra.

These references are categorized as under.

- Utilization in Therapeutics

1) Internal Use

2) External Use

Utilization in preparation of equipment/ instrument.

Utilization in showing similarity between things. (Drushtaant)

SHILAJATU:
Rasashastra classification
Latin Name
English Name
Maharas varga
Asphaltum punjabinum
Black Bitumen or
Mineral Pitch.

Shilajatu is one of the few mineral compounds whose internal use is described in Kashyap Samhita. In Rasaratnasamuchhaya, which is considered as most prime reference book in Rasashastra written by Rasvagbhat, there are references of use of Shilajatu for internal administration.(8)

Table No. 2: Table showing references of Shilajatu in Kashyap Samhita.

\begin{tabular}{|c|c|c|}
\hline $\begin{array}{c}\text { Sr. } \\
\text { No. }\end{array}$ & Formulation & Use \\
\hline $\begin{array}{c}\text { Utilization in therapeutic - Internal } \\
\text { administration }\end{array}$ & Shilajatu (9) & $\begin{array}{c}\text { Internal administration } \\
\text { in Raktagulma }\end{array}$ \\
\hline 1 & \multicolumn{3}{|c|}{} \\
\hline \multicolumn{3}{|c|}{ Utilization in therapeutic - External use } \\
\hline 2 & $\begin{array}{c}\text { Kumar Dhoop } \\
(10)\end{array}$ & Dhoopan (Fumigation) \\
\hline
\end{tabular}

\section{GAIRIK: \\ Rasashastra classification \\ Latin Name \\ English Name}

Uparas Varga.

Red Ochre

Ochre/ Haematite.

There are two types of Gairik.

Pashan Gairik - Hard - Tamravarna

Swarna Gairik - Soft- Raktavarna.

Of these two types Swarna Gairik is useful for medicinal purpose.(11)

Table No. 3: Table showing references of Gairik in Kashyap Samhita.

\begin{tabular}{|c|c|c|}
\hline $\begin{array}{c}\text { Sr. } \\
\text { No. }\end{array}$ & Formulation & Use \\
\hline \multicolumn{3}{|c|}{ Utilization in Therapeutics - External application } \\
\hline 1 & $\begin{array}{c}\text { Lohitika Gutika } \\
(12)\end{array}$ & Anjan in Akshirog \\
\hline 2 & Lepa $(13)$ & Lepan in Visarpa \\
\hline
\end{tabular}


KASIS

\section{Rasashastra Classification Uparas Varga. \\ English Name Green Vitriol.}

In Rasashastra text, emphasis is given on external application of Kasis. When used internally it shows the property of Rajah-Pravartan (stimulates Menstruation) (14)

Table No. 4: Table showing references of $K$ asis in Kashyap Samhita.

\begin{tabular}{|c|c|c|}
\hline $\begin{array}{c}\text { Sr. } \\
\text { No. }\end{array}$ & Formulation & Use \\
\hline \multicolumn{2}{|c|}{ Utilization in Therapeutics- External Use } \\
\hline 1 & $\begin{array}{c}\text { Sawarnakar Yoga } \\
(15)\end{array}$ & $\begin{array}{c}\text { Restoration of Skin } \\
\text { colour }\end{array}$ \\
\hline
\end{tabular}

\section{HARTAAL}

Rasashastra Classification Uparas Varga

English Name Orpiment

Hartaal is Arsenic trisulphide. Hartaal Bhasma is Ushna Virya with properties such as Snigdha and Guru.(16)

Table No. 5: Table showing references of Hartaal in Kashyap Samhita.

\begin{tabular}{|c|c|c|}
\hline $\begin{array}{c}\text { Sr. } \\
\text { No. }\end{array}$ & Formulation & Use \\
\hline \multicolumn{2}{|c|}{ Utilization in Therapeutics- External Use } \\
\hline 1 & Sidhha Taila(17) & $\begin{array}{c}\text { Abhyang in } \\
\text { Putanagraha } \\
\text { chikitsa }\end{array}$ \\
\hline 2 & Gudavarti(18) & $\begin{array}{c}\text { Suppository in } \\
\text { Udavart }\end{array}$ \\
\hline
\end{tabular}

\section{MANASHILA}

\section{Rasashastra Classification Uparas Varga. English Name \\ Realgar}

Manashila is Arsenic disulphide. It is quoted as useful in Raktvikar. It also has property of Bhutopdrav Nashini.(19)

Table No. 6: Table showing references of Manashila in Kashyap Samhita.

\begin{tabular}{|c|c|c|}
\hline $\begin{array}{c}\text { Sr. } \\
\text { No. }\end{array}$ & Formulation & Use \\
\hline \multicolumn{2}{|c|}{ Utilization in Therapeutics- External Use } \\
\hline 1 & Sidhha Taila(17) & $\begin{array}{c}\text { Abhyang in Putna } \\
\text { Chikitsa }\end{array}$ \\
\hline 2 & Gudavarti(18) & $\begin{array}{c}\text { Suppository in } \\
\text { Udavart }\end{array}$ \\
\hline 3 & $\begin{array}{c}\text { Savarnakar Yoga } \\
(15)\end{array}$ & $\begin{array}{c}\text { Lepa in Vran } \\
\text { Local application } \\
\text { or Abhyangn in } \\
\text { Arunshika (Eczema } \\
\text { of scalp) }\end{array}$ \\
\hline 4 & $\begin{array}{c}\text { Raskriya/Taila(20) } \\
\text { Anjan in Akshirog }\end{array}$ \\
\hline 5 & Netravarti(21) & . \\
\hline
\end{tabular}

PUSHPAK / PUSHPANJAN

Rasashastra Classification Uparas Varga. English Name

White Zinc,

Flower of Zinc.

Zinc oxide is considered as Pushpanjan and is used in pathological conditions relating to eye. (External application)

Properties of Pushpanjan has been given in Kashyap Samhita. It is said to be Tikshna, Ushna, Malhar, Rakt-Pitta-Kapha Paham, Drushtiprasadan. (22)

Table No. 7: Table showing references of Pushpanjan/Pushpak in Kashyap Samhita

\begin{tabular}{|c|c|c|}
\hline $\begin{array}{c}\text { Sr. } \\
\text { No. }\end{array}$ & Formulation & Use \\
\hline \multicolumn{3}{|c|}{ Utilization in Therapeutics- External Use } \\
\hline 1 & Raskriya(22) & Akshirog \\
\hline 2 & Anjan(22) & Akshirog \\
\hline 3 & Anjan(22) & Akshirog \\
\hline
\end{tabular}

\section{SWARNA}

\section{Rasashastra Classification Loha Varga}

$\begin{array}{ll}\text { Latin Name } & \text { (Saar Loha) } \\ \text { English Name } & \text { Aurum } \\ & \text { Gold }\end{array}$

Swarna has been known to mankind since Vaidik Times. It is noble metal used for ornament making since long time.

Internal use of Swarna Bhasma is Medhya, Bruhan, Vrushya.(23)

In Kashyap Samhita, Gold is the second Rasashastra entity that is used in internal use. In Sutrasthaan Lehadhyay, Kashyap have described procedure of Suvarnaprashana. It is said to be Medhya, Agni and Bal -vardhaka. Administration for 1 month gives Parammedhavi child while use for 6 month makes child Shrutdhar (Child memorizes whatever he listens once) (24).

Table No. 8: Table showing reference of Swarna in Kashyap Samhita

\begin{tabular}{|c|c|c|}
\hline & Formulation & Use \\
\hline \multicolumn{3}{|c|}{ Utilization in Therapeutics- Internal Use } \\
\hline 1 & $\begin{array}{c}\text { Suvarnaprashan } \\
(24)\end{array}$ & $\begin{array}{c}\text { Lehan in healthy } \\
\text { Child }\end{array}$ \\
\hline \multicolumn{3}{|c|}{ Utilization in Therapeutics- External Use } \\
\hline 2 & $\begin{array}{c}\text { Akshipuran Yoga } \\
(25)\end{array}$ & Akshirog \\
\hline
\end{tabular}




\section{Vaibhav B Yeokar et.al., Review of Rasashastra Dravya in Classical Text of Ayurveda-Kashyap Samhita}

Table No. 9: Table showing reference of Swarna in preparation of equipment/instrument/pots

\begin{tabular}{|c|c|c|}
\hline $\begin{array}{c}\text { Sr. } \\
\text { No. }\end{array}$ & Description & $\begin{array}{c}\text { Probable } \\
\text { Translation }\end{array}$ \\
\hline 1 & $\begin{array}{c}\text { Toyapurn Bhajan } \\
(26)\end{array}$ & $\begin{array}{c}\text { Pot filled with } \\
\text { water }\end{array}$ \\
\hline 2 & Bhajan(27) & Pot \\
\hline 3 & Mani(28) & $\begin{array}{c}\text { Small pebble like } \\
\text { structure }\end{array}$ \\
\hline 4 & Hiranyapani(29) & $\begin{array}{c}\text { Anything made of } \\
\text { Gold to be held in } \\
\text { hand }\end{array}$ \\
\hline
\end{tabular}

Table No. 10: Table showing references of using Swarna as an example (Drushtant)

\begin{tabular}{|c|c|c|}
\hline $\begin{array}{c}\text { Sr. } \\
\text { No. }\end{array}$ & Description & $\begin{array}{c}\text { Probable } \\
\text { Translation }\end{array}$ \\
\hline 1 & $\begin{array}{c}\text { Swarna churna } \\
\text { sadrushya Ashmari } \\
(30)\end{array}$ & $\begin{array}{c}\text { Stones resembling } \\
\text { Gold powder }\end{array}$ \\
\hline 2 & $\begin{array}{c}\text { Hiranya kurvanti } \\
\text { Ye Anruta(31) }\end{array}$ & $\begin{array}{c}\text { Faulty practices } \\
\text { regarding Swarna }\end{array}$ \\
\hline 3 & $\begin{array}{c}\text { Swarna Maladhari } \\
\text { Jaatharini(32) }\end{array}$ & $\begin{array}{c}\text { Jaatharini wearing } \\
\text { Gold necklace }\end{array}$ \\
\hline
\end{tabular}

\section{RAJAT}

Rasashastra Classification Loha Varga

(Saar Loha)

English Name

Silver

Latin Name

Argentinum

Rajat is another noble metal used for making ornaments and pots since long time.

Rajat Bhasma is Sheet Virya and is Snigdha, Guru, and Sar.(33)

Rajat Bhasma is specifically indiacted for Koshthagat vaat. It is also useful for students and those persons who are engaged in mental activities.(34)

In Kashyap Samhita, various references show that pots of Silver were extensively used for various purposes.

Table No. 11: Table showing references of Rajat in preparation of equipments/instruments/pots

\begin{tabular}{|c|c|c|}
\hline $\begin{array}{c}\text { Sr. } \\
\text { No. }\end{array}$ & Description & $\begin{array}{c}\text { Probable } \\
\text { Translation }\end{array}$ \\
\hline 1 & $\begin{array}{c}\text { Kshiren Rajate } \\
\text { Patre....(35) }\end{array}$ & $\begin{array}{c}\text { Pot for drinking } \\
\text { milk }\end{array}$ \\
\hline 2 & Rajat Bhaajan(27) & $\begin{array}{c}\text { Pot for making } \\
\text { Basti }\end{array}$ \\
\hline 3 & Rajat Mani(28) & $\begin{array}{c}\text { Small pebble like } \\
\text { structure }\end{array}$ \\
\hline 4 & Rajat Bhaajan(26) & Pot \\
\hline
\end{tabular}

TAMRA

Rasashastra Classification Loha Varga

(Sadharan Loha)

English Name

Copper

Latin Name

Cuprum

Copper is being used in making Coins, Pots, Ornaments and other equipment since long time. Even today Copper wires are widely used for making electrical cables.

Because of its Lekhan Guna, use of Tamra in eye diseases is also accepted by Rasashastra texts.(36)

In Kashyap Samhita also, Tamra is used in treatment of Kukkunak, an ophthalmic condition affecting primarily children of breast feeding age.

Table No. 12: Table showing references of Tamra in Kashyap Samhita.

\begin{tabular}{|c|c|c|}
\hline $\begin{array}{c}\text { Sr. } \\
\text { No. }\end{array}$ & Formulation & Use \\
\hline Utilization in Therapeutics- External Use \\
\hline 1 & Anjan $(22)$ & Akshirog \\
\hline 2 & Anjanvartika $(12)$ & Kukkunak \\
\hline
\end{tabular}

Table No. 13: Table showing references of using Tamra Patra as equipment of formulation.

\begin{tabular}{|c|c|c|}
\hline $\begin{array}{c}\text { Sr. } \\
\text { No. }\end{array}$ & Description & $\begin{array}{c}\text { Probable } \\
\text { Translation }\end{array}$ \\
\hline 1 & Tamra-Patt(37) & Copper Plate \\
\hline 2 & Tamra-Patra $(37)$ & Copper pot \\
\hline 3 & Tamra-Patra $(37)$ & Copper pot \\
\hline 4 & Tamra-Patt(37) & Copper plate \\
\hline
\end{tabular}

\section{LOHA}

Rasashastra Classification

Loha Varga

English Name

(Sadharan Loha)

Latin Name

Iron

Ferrum

Loha Bhasma Guna- Rasayan, Vajikaran, Balya, Vrishya, Medhya, Chakshushya(38)

Loha is third Rasa Dravya which is quoted for internal use by Kashyap Samhita.

Table No. 14: Table showing references of Loha in Kashyap Samhita.

\begin{tabular}{|c|c|c|}
\hline $\begin{array}{c}\text { Sr. } \\
\text { No. }\end{array}$ & Formulation & Use \\
\hline Utilization in Therapeutics- Internal Use \\
\hline 1 & Churna(39) & $\begin{array}{c}\text { Taken orally for } \\
\text { treatment of Shotha }\end{array}$ \\
\hline 2 & Churna(39) & $\begin{array}{c}\text { Taken orally for } \\
\text { treatment of Shotha }\end{array}$ \\
\hline 3 & $\begin{array}{c}\text { Katukbindu Leha } \\
(40)\end{array}$ & \begin{tabular}{c} 
Lehan in Shotha \\
\multicolumn{3}{|c|}{}
\end{tabular} \\
\hline 4 & $\begin{array}{c}\text { Savarnakar Yoga } \\
(15)\end{array}$ & Lepa in Vran \\
\hline 5 & Anjanvartika(40) & Anjan in Kukkunak \\
\hline
\end{tabular}


KANSYA

Rasashastra Classification

Loha Varga

(Mishr Loha)

English Name

Bronze

Kansya is prepared by melting together 8 parts of Copper and 2 parts of Tin. Knowledge of Bronze is from centuries, since we can see bells hung at the entrance of Hindu temples are made up of Bronze.

Though internal use of Kansya is seen in Rasashastra texts only, it's use for external application as well as for pot making is seen in Kashyap Samhita also.

Table No. 15: Table showing references of Kansya in Kashyap Samhita

\begin{tabular}{|c|c|c|}
\hline $\begin{array}{c}\text { Sr. } \\
\text { No. }\end{array}$ & Formulation & Use \\
\hline 1 & Anjan(22) & Netraroga \\
\hline
\end{tabular}

Table No. 16: Table showing references of Kansya for making equipment/instrument/pots.

\begin{tabular}{|c|c|c|}
\hline $\begin{array}{c}\text { Sr. } \\
\text { No. }\end{array}$ & Description & Probable Translation \\
\hline 1 & $\begin{array}{c}\text { Kshiren Kansye } \\
\text { Patre....(35) }\end{array}$ & Pot for drinking milk \\
\hline 2 & $\begin{array}{c}\text { Kansya Patra } \\
(22)\end{array}$ & $\begin{array}{c}\text { Pot for preparation of } \\
\text { Anjan }\end{array}$ \\
\hline 3 & Basti Patra(27) & $\begin{array}{c}\text { Pot for preparation of } \\
\text { Basti }\end{array}$ \\
\hline 4 & Mani(28) & $\begin{array}{c}\text { Small pebble like } \\
\text { structure }\end{array}$ \\
\hline 5 & Bhajan(26) & Pot \\
\hline & & \\
\hline
\end{tabular}

$N \boldsymbol{A} \boldsymbol{A}$

Rasashastra Classification Loha Varga (Puti Loha) English Name

Latin Name

Lead

Plumbum

Guna of Naga Bhasma - Prameha Nashak, Vrana, Arsha, Gulma, Grahanee, Atisar Nashak.(42)

Table No. 17: Table showing reference of Naga in preparation of instrument/equipment.

\begin{tabular}{|c|c|c|}
\hline $\begin{array}{c}\text { Sr. } \\
\text { No. }\end{array}$ & Description & Probable translation \\
\hline 1 & Mani(28) & Small pebble like structure. \\
\hline
\end{tabular}

MUKTA

$\begin{array}{ll}\text { Rasashastra Classification } & \text { Ratna Varga } \\ \text { English name } & \text { Pearl. }\end{array}$

Mukta is Pearl obtained from oyster shells. It is beautiful gem which is reason why it is included in Ratna Varga.

Kashyap Samhita have quoted use of Mukta at two places.
Table No. 18: Table showing references of Mukta in Kashyap Samhita

\begin{tabular}{|c|c|c|}
\hline $\begin{array}{c}\text { Sr. } \\
\text { no. }\end{array}$ & Formulation & Use \\
\hline \multicolumn{3}{|c|}{ Utilization in Therapeutics- External Use } \\
\hline 1 & $\operatorname{Lepa}(41)$ & Local application in Visarp \\
\hline
\end{tabular}

Table No. 19: Table showing references of Mukta for use other than medicinal purpose

\begin{tabular}{|c|c|c|}
\hline $\begin{array}{c}\text { Sr. } \\
\text { No. }\end{array}$ & Description & Use \\
\hline 1 & Mukta(28) & $\begin{array}{c}\text { Mukta is taken in Shashthi } \\
\text { Pooja ceremony }\end{array}$ \\
\hline
\end{tabular}

$\operatorname{PR} A \boldsymbol{V A L}$

Rasashastra Classification Ratna Varga.

English Name Coral

Corals are dead and calcified bodies of marine animal Anthazoan polyps. Chemically it is Calcium Carbonate. Praval which is pink or red in colour are considered as Ratna by Rasashastra textbooks.

Kashyap Samhita has quoted Praval in following reference.

Table no. 20: Table showing references of Praval in Kashyap Samhit

\begin{tabular}{|c|c|c|}
\hline $\begin{array}{c}\text { Sr. } \\
\text { No. }\end{array}$ & Description & Use \\
\hline 1 & Praval(28) & $\begin{array}{c}\text { Praval is taken in } \\
\text { Shashthi Pooja ceremony }\end{array}$ \\
\hline
\end{tabular}

\section{VAJRA}

\section{Rasashastra Classification Ratna Varga \\ English Name Diamond}

On Moh's hardness scale, the hardness of Vajra is found to be 10. It is allotropic form of Carbon in which atoms are tightly bound giving rise to hard and transparent structure.

Vajra Bhasma Guna - Hridya, Yogavahi, Rasayan, Medhya, Vajikar, Netrya, Varnya.(44)

Table No. 21: Table showing references of using Vajra as an example (Drushtant) in Kashyap Samhita

\begin{tabular}{|l|l|c|}
\hline $\begin{array}{l}\text { Sr. } \\
\text { No. }\end{array}$ & Description & Probable Translation \\
\hline 1 & Vajra Tunda- & Diamond like hard nails, \\
& $\begin{array}{c}\text { Nakha-Dashan } \\
\text { teeth and stings of } \\
\end{array}$ & Jaatharini \\
\hline
\end{tabular}

\section{SHANKHA}

\section{Rasa-shastra Classification Sudha Varga.

English Name Conch Shell

It is an outer shell of Molluscum class animal living in oceans. Chemically it is Calcium Carbonate. According to Hindu mythology, during Samudra Manthan, Shankh appeared from Kshirsagar.

Bhasma is noted.(45) 
Table No. 22: Table showing references of Shankh in Kashyap Samhita

\begin{tabular}{|l|c|c|}
\hline $\begin{array}{l}\text { Sr. } \\
\text { No. }\end{array}$ & Formulation & Use \\
\hline \multicolumn{3}{|l|}{ Utilization in Therapeutics - Internal Use } \\
\hline 1 & Apup(37) & $\begin{array}{c}\text { For oral intake in } \\
\text { Akshiroga }\end{array}$ \\
\hline \multicolumn{2}{|l|}{ Utilization in Therapeutics - External Use } \\
\hline 2 & Anjanvartika(41) & Anjan in Akshirog \\
\hline 3 & Gudika(12) & Timir, Koth \\
\hline 4 & Aashyotan(12) & Akshirog \\
\hline 5 & Sidhha Taila(37) & Akshirog \\
\hline 6 & Lepa(43) & Visarpa \\
\hline
\end{tabular}

\section{VISHA DRAVYA}

In Rasa-shastra, use of Visha Dravya or poisonous compounds is done for various purposes like Raskarma, Rasbandhan etc.(46) According to classical text of Rasa-shastra Visha-Dravya are chiefly divided under two headings.

Visha-Vatsanabh etc. ( Total 9 in number)

Upvisha-Vishtinduk etc. ( Total 11 in number)(47)

Table no. 23: Table showing references of Visha Dravya in Kashyap Samhita

\begin{tabular}{|c|c|c|c|}
\hline $\begin{array}{c}\text { Sr. } \\
\text { No. }\end{array}$ & $\begin{array}{c}\text { Name of } \\
\text { Drug }\end{array}$ & Formulation & Use \\
\hline 1 & $\begin{array}{c}\text { Sudha } \\
\left(\begin{array}{c}\text { Snuhi) } \\
(48)\end{array}\right.\end{array}$ & $\begin{array}{c}\text { Mahabhayaris } \\
\text { hta }\end{array}$ & $\begin{array}{c}\text { Kaphaj } \\
\text { ailments }\end{array}$ \\
\hline 2 & $\begin{array}{c}\text { Danti(48) } \\
\text { Mahabhayaris } \\
\text { hta }\end{array}$ & $\begin{array}{c}\text { Kaphaj } \\
\text { ailments }\end{array}$ \\
\hline 3 & $\begin{array}{c}\text { Langli } \\
(49)\end{array}$ & $\begin{array}{c}\text { Powder for } \\
\text { inhalation }\end{array}$ & $\begin{array}{c}\text { Prolonged } \\
\text { labour }\end{array}$ \\
\hline 4 & $\begin{array}{c}\text { Bhallatak } \\
(50)\end{array}$ & $\begin{array}{c}\text { Dashang } \\
\text { Dhoop }\end{array}$ & $\begin{array}{c}\text { Dhoopan } \\
\text { (Fumigatio } \\
\mathrm{n})\end{array}$ \\
\hline
\end{tabular}

\section{Discussion}

Kashyap Samhita is one of the oldest Samhita dating back to year 600 B.C. Due to fact that a large part of this Samhita is missing; knowledge of some topics has been remained hidden. Still this Samhita guides us very well towards different subjects such as Child Care on which Kashyap have primarily focused. With this primary subject, Kashyap have also covered other entities of Ayurveda as well.

It becomes clear from screening of Kashyap Samhita that metals like Gold, Iron and mineral compounds like Shilajatu and Shankha were used in internal as well as external administration. Meanwhile other metals and minerals like Silver, Copper, Orpiment, Realgar etc. were in use for external application in various forms like Anjan or Sidhha Taila etc.

In addition to this, there are some references which show that different metals like Silver, Copper, Iron, Bronze etc. were in use for making different pots essential either for medicinal preparation or medicine storage.

To explain things by giving example of other similar thing is called as Drushtant. In Kashyap Samhita, there are references where we can deduce presence of Drushtant. In these Drushtant, various Rasadravya are used as an example.

\section{Conclusion}

Reviewing Kashyap Samhita reveals that use of metals, minerals etc. is found since long time. It is generally thought that Ayurveda classics of "Samhita Time" such as Charak and Sushrut have their share in development of Rasashastra during it's initial stage.

From having looked at references mentioned in above article, it is clear that Kashyap Samhita have also dealt significantly in development of Rasashastra.

Unfortunately due to unavailability of larger part of this Samhita, it has become difficult to establish proper meaning of some part of text like Baalgraha, Jaatharini etc.

Therefore it has become necessity to study Kashyap Samhita from various point of view of Ayurveda. This research paper was an attempt to study from Rasashastra perspective. Scholars would be delighted to know how immense research one can carry out in this Samhita and bring new knowledge in front of the world.

\section{References}

1) Agnivesha. Shukla Vidhyadhar, Tripathi Ravidatta, commentary. Charak Samhita(Purvardha). Delhi; Chaukhambha Sanskrit Pratishthan; 2010. p.447

2) Acharya Sushrut. Shastri Ambikadatta, commentary. Sushrut Samhita. Varanasi; Chaukhambha Sanskrit Sansthan; 2010. p.5

3) Acharya Sushrut. Shastri Ambikadatta, commentary. Sushrut Samhita. Varanasi; Chaukhambha Sanskrit Sansthan; 2010. p.6

4) Vagbhatacharya. Tripathi Indradev, commentary. Rasaratnasamuchchaya. Varanasi; Chaukhambha Sanskrit Sansthan; 2013. p.371

5) Agnivesha. Shukla Vidhyadhar, Tripathi Ravidatta, commentary. Charak Samhita(Uttarardha). Delhi; Chaukhambha Sanskrit Pratishthan; 2010. p.190

6) Acharya Sushrut. Shastri Ambikadatta, commentary. Sushrut Samhita. Varanasi; Chaukhambha Sanskrit Sansthan; 2010. p.73

7) Vagbhatacharya. Tripathi Indradev, commentary. Rasaratnasamuchchaya. Varanasi; Chaukhambha Sanskrit Sansthan; 2013. p.371

8) Vagbhatacharya. Tripathi Indradev, commentary. Rasaratnasamuchchaya. Varanasi; Chaukhambha Sanskrit Sansthan; 2013. p.21

9) Vrudhhajivaka. Satyapal Bhishagacharya, commentary. Kashyap Samhita. Varanasi; Chaukhambha Sanskrit Sansthan; 2012. p.292

10) Vrudhhajivaka. Satyapal Bhishagacharya, commentary. Kashyap Samhita. Varanasi; Chaukhambha Sanskrit Sansthan; 2012. p.170

11) Vagbhatacharya. Tripathi Indradev, commentary. 
Rasaratnasamuchchaya. Varanasi; Chaukhambha Sanskrit Sansthan; 2013. p.29

12) Vrudhhajivaka. Satyapal Bhishagacharya, commentary. Kashyap Samhita. Varanasi; Chaukhambha Sanskrit Sansthan; 2012. p.322

13) Vrudhhajivaka. Satyapal Bhishagacharya, commentary. Kashyap Samhita. Varanasi; Chaukhambha Sanskrit Sansthan; 2012. p.328

14) Sharma Sadanand. Shastri Kashinath, editor. Rasatarangini. Delhi; Motilal Banarasidas; 1979.p. 564

15) Vrudhhajivaka. Satyapal Bhishagacharya, commentary. Kashyap Samhita. Varanasi; Chaukhambha Sanskrit Sansthan; 2012. p.126

16) Sharma Sadanand. Shastri Kashinath, editor. Rasatarangini. Delhi; Motilal Banarasidas; 1979.p. 252

17) Vrudhhajivaka. Satyapal Bhishagacharya, commentary. Kashyap Samhita. Varanasi; Chaukhambha Sanskrit Sansthan; 2012. p.102

18) Vrudhhajivaka. Satyapal Bhishagacharya, commentary. Kashyap Samhita. Varanasi; Chaukhambha Sanskrit Sansthan; 2012. p.107

19) Sharma Sadanand. Shastri Kashinath, editor. Rasatarangini. Delhi; Motilal Banarasidas; 1979.p. 262

20) Vrudhhajivaka. Satyapal Bhishagacharya, commentary. Kashyap Samhita. Varanasi; Chaukhambha Sanskrit Sansthan; 2012. p.128

21) Vrudhhajivaka. Satyapal Bhishagacharya, commentary. Kashyap Samhita. Varanasi; Chaukhambha Sanskrit Sansthan; 2012. p.161

22) Vrudhhajivaka. Satyapal Bhishagacharya, commentary. Kashyap Samhita. Varanasi; Chaukhambha Sanskrit Sansthan; 2012. p.184

23) Sharma Sadanand. Shastri Kashinath, editor. Rasatarangini. Delhi; Motilal Banarasidas; 1979.p. 367

24) Vrudhhajivaka. Satyapal Bhishagacharya, commentary. Kashyap Samhita. Varanasi; Chaukhambha Sanskrit Sansthan; 2012. p.5

25) Vrudhhajivaka. Satyapal Bhishagacharya, commentary. Kashyap Samhita. Varanasi; Chaukhambha Sanskrit Sansthan; 2012. p.183

26) Vrudhhajivaka. Satyapal Bhishagacharya, commentary. Kashyap Samhita. Varanasi; Chaukhambha Sanskrit Sansthan; 2012. p.348

27) Vrudhhajivaka. Satyapal Bhishagacharya, commentary. Kashyap Samhita. Varanasi; Chaukhambha Sanskrit Sansthan; 2012. p.280

28) Vrudhhajivaka. Satyapal Bhishagacharya, commentary. Kashyap Samhita. Varanasi; Chaukhambha Sanskrit Sansthan; 2012. p.316

29) Vrudhhajivaka. Satyapal Bhishagacharya, commentary. Kashyap Samhita. Varanasi; Chaukhambha Sanskrit Sansthan; 2012. p.199

30) Vrudhhajivaka. Satyapal Bhishagacharya, commentary. Kashyap Samhita. Varanasi; Chaukhambha Sanskrit Sansthan; 2012. p.121

31) Vrudhhajivaka. Satyapal Bhishagacharya, commentary. Kashyap Samhita. Varanasi; Chaukhambha Sanskrit Sansthan; 2012. p.191

32) Vrudhhajivaka. Satyapal Bhishagacharya, commentary. Kashyap Samhita. Varanasi; Chaukhambha Sanskrit Sansthan; 2012. p.196

33) Vagbhatacharya. Tripathi Indradev, commentary. Rasaratnasamuchchaya. Varanasi; Chaukhambha Sanskrit Sansthan; 2013. p.55

34) Sharma Sadanand. Shastri Kashinath, editor. Rasatarangini. Delhi; Motilal Banarasidas; 1979.p. 395

35) Vrudhhajivaka. Satyapal Bhishagacharya, commentary. Kashyap Samhita. Varanasi; Chaukhambha Sanskrit Sansthan; 2012. p.82

36) Vagbhatacharya. Tripathi Indradev, commentary. Rasaratnasamuchchaya. Varanasi; Chaukhambha Sanskrit Sansthan; 2013. p.55

37) Vrudhhajivaka. Satyapal Bhishagacharya, commentary. Kashyap Samhita. Varanasi; Chaukhambha Sanskrit Sansthan; 2012. p.323

38) Vagbhatacharya. Tripathi Indradev, commentary. Rasaratnasamuchchaya. Varanasi; Chaukhambha Sanskrit Sansthan; 2013. p.57

39) Vrudhhajivaka. Satyapal Bhishagacharya, commentary. Kashyap Samhita. Varanasi; Chaukhambha Sanskrit Sansthan; 2012. p.341

40) Vrudhhajivaka. Satyapal Bhishagacharya, commentary. Kashyap Samhita. Varanasi; Chaukhambha Sanskrit Sansthan; 2012. p.342

41) Vrudhhajivaka. Satyapal Bhishagacharya, commentary. Kashyap Samhita. Varanasi; Chaukhambha Sanskrit Sansthan; 2012. p.321

42) Acharya Shri Madhav. Mishra Gulraj Sharma, commentary. Ayurved Prakash. Varanasi; Chaukhambha Bharati Academy; 1987. p. 323

43) Vrudhhajivaka. Satyapal Bhishagacharya, commentary. Kashyap Samhita. Varanasi; Chaukhambha Sanskrit Sansthan; 2012. p.328

44) Sharma Sadanand. Shastri Kashinath, editor. Rasatarangini. Delhi; Motilal Banarasidas; 1979.p. 604

45) Acharya Shri Madhav. Mishra Gulraj Sharma, commentary. Ayurved Prakash. Varanasi; Chaukhambha Bharati Academy; 1987. p. 382

46) Vagbhatacharya. Tripathi Indradev, commentary. Rasaratnasamuchchaya. Varanasi; Chaukhambha Sanskrit Sansthan; 2013. p.66

47) Sharma Sadanand. Shastri Kashinath, editor. Rasatarangini. Delhi; Motilal Banarasidas; 1979.p. 648

48) Vrudhhajivaka. Satyapal Bhishagacharya, commentary. Kashyap Samhita. Varanasi; Chaukhambha Sanskrit Sansthan; 2012. p.110

49) Vrudhhajivaka. Satyapal Bhishagacharya, commentary. Kashyap Samhita. Varanasi; Chaukhambha Sanskrit Sansthan; 2012. p.86

50) Vrudhhajivaka. Satyapal Bhishagacharya, commentary. Kashyap Samhita. Varanasi; Chaukhambha Sanskrit Sansthan; 2012. p.471. 